\title{
STRUKTUR DASAR SASTRA LISAN DEDER
}

\section{The Basic Structure Of Deder's Oral Literature}

\author{
Oleh: Misnawati*, Petrus Poerwadi**, dan Fitria Meta Rosia*** \\ e-mail: misnawati.sani@yahoo.co.id
}

\begin{abstract}
ABSTRAK
Tujuan penelitian ini adalah mendeskripsikan struktur sastra lisan deder yang berhubungan dengan struktur dasar berupa bait dan baris.Teknik pengumpulan data dalam penelitian ini menggunakan: (1) teknik perekaman, baik audio maupun audiovisual, (2) pencatatan, (3) wawancara yang mendalam, (4) studi kepustakaan dan analisis dokumentasi. Sumber data utama yang dianalisis adalah teks deder yang ada di kota Palangka Raya Kalimantan Tengah.

Pemeriksaan keabsahan data dalam penelitian kualitatif ini mengikuti yang disarankan Lincoln dan Gube, meliputi empat teknik: (1) credibility (kredibilitas, merupakan kriteria untuk memenuhi nilai kebenaran dari data dan informasi yang dikumpulkan);(2) transferability (transferbilitas, merupakan kriteria yang digunakan untuk memenuhi kriteria bahwa hasil penelitian yang dilakukan dalam konteks tertentu dapat ditransfer ke subjek lain yang memiliki tipologi yang sama);(3) dependability (dependabilitas, digunakan untuk menilai apakah proses penelitian kualitatif bermutu atau tidak);dan(4) confirmability (konfirmabilitas, yaitu kriteria untuk menilai bermutu - tidaknya hasil penelitian).

Data yang telah dikumpul dianalisis dengan menggunakan teori Struktural Dinamik.Teori Struktural Dinamik dimanfaatkan secara metodologis untuk menganalisisrumusan masalah penelitian.Temuan penelitian berupa struktur bait dalam deder, berbentuk: (1) Jumlah bait dalam setiap deder tidak tentu, bergantung topik dan kreativitas pendeder. (2) Setiap bait deder terdiri atas dua baris. (3) Struktur bait deder terdiri atas: pembukaan, isi, dan penutup. (4) Bait pembukaan, isi, dan penutup dinyanyikan oleh pendeder Perempuan maupun Lakilaki.Struktur baris dalam deder, berbentuk: (1) jumlah kata dalam satu baris adalah tiga sampai tujuh kata. (2) jumlah suku kata dalam setiap barisnya adalah delapan sampai tiga belas suku kata. (3) baris pertama dapat berupa pengumpan, dapat pula bertautan makna dengan baris.
\end{abstract}

\section{Kata Kunci: Deder, Representasi, Struktur ,kultural}

\section{ABSTRACT}

The purpose of this study was to describe the structure of deder oral literature related to the basic structure of the bait and line.The data techniques in this study used: (1) recording techniques, both audio and audiovisual, (2) recording, (3) in-depth interviews, (4) literature study and documentation analysis. The main data source analyzed was the existing text in the city of Palangka Raya, Central Kalimantan.

Checking the validity of the data in this qualitative study follows those based on Lincoln and Gube, including four techniques: (1) credibility, a criterion for meeting the truth value of the data and information collected); (2) transferability (the criteria used to meet the criteria) transferability that the results of research conducted in a particular context can be transferred to other subjects who have the same typology); (3) dependability (dependability, used to Misnawati*, Petrus Poerwadi**, dan Fitria Meta Rosia*** 
assess whether the qualitative research process is qualified or not); and (4) confirmability, namely the criteria for assessing the quality of the research results.

The data that has been collected were analyzed using dynamic structural theory. Dynamic Structural Theory is used methodologically to analyze the formulation of research problems.The findings of this research are the structure of the bait in the deder, in the form of: (1) The number of bait in each deder is uncertain, the topic and creativity of the pendeder. (2) Each feed consists of two lines. (3) Deder feed structure consists of: opening, filling and closing. (4) The opening, filling and closing stanza is sung by male and female pendeder. The line structure in deder, takes the form of: (1) the number of words in one line is three to seven words. (2) the number of syllables in each line is eight to thirteen syllables. (3) the first row can be in the form of a feeder, it can also be linked to the meaning of the line.

Keyword: Deder, Representation, Structure, culture

\section{PENDAHULUAN}

Deder adalah sastra lisan Dayak Ngaju yang masih hidup sampai sekarang. Sebagai sebuah karya sastra, deder berbentuk puisi. Deder berisikan nasihat, sindiran, atau petuah. Deder lazimnya dinyanyikan secara bergantian antara Lakilaki dan Perempuan, antara Perempuan dan Perempuan, atau antara Laki-laki dan Lakilaki. Deder dilantunkan dalam acara adat, hiburan seperti pernikahan dan hajatan, serta untuk menyambut para tamu. Biasanya deder dilantunkan sambil diiringi tarian Manasai. Pelantun deder dapat berasal dari semua kalangan artinya siapa saja yang dapat melantunkan deder maka diizinkan untuk melantunkannya.Deder lazimnyadilantunkan bersama dengan taritarian yang dilakukan berpasangan Lakilaki dan Perempuan, boleh juga bergantian. Para penari mengelilingi sebuah sangkai atau tiang, boleh di dalam boleh juga di halaman rumah (Riwut 2003: 106).

Para penari dengan diiringi suara musik menyanyikan puisi-puisi deder secaraserta merta, bersahut-sahutan sambil sindir-menyindir dengan jenaka hingga membuat para penonton tertawa dan bergembira. Oleh karena dilantunkan secara serta merta, deder menguji kreativitas pededer (pelantun deder).
Pededer harus pandai dalam melontarkan pertanyaan kepada lawannya, oleh karena itu, deder biasanya dapat berlangsung lama, tergantung dari apakah masingmasing pededer dapat terus menjawab pertanyaan dari lawan mereka. Deder ini akan terus berlanjut hingga salah satu pededer kalah. Sebagai sastra lisan, deder mengekspresikan pikiran dan perasaan pelantun deder. Deder bukanlah puisi biasa. Deder mewadahi dan mengekspresikan konsep budaya masyarakat Dayak. Di dalam deder terdapat nilai-nilai budaya. Identitas budaya juga diungkap dalam puisi deder. Meskipun deder menjadi alat pengungkap pikiran dan perasaan, namun deder sudah tidak lagi sering dilantunkan. Jika hal ini dibiarkan, tentu deder akan hilang dan menjadi sastra lisan yang mati. Perlu usaha untuk memlihara dan menghidupkan deder agar tetap hidup dan berkembang. Pelestarian dan pengembangan deder perlu dilakukan, sebab deder dapat dijadikan alat untuk mengembangkan karakter bangsa. Sastra lisan daerah memiliki kedudukan yang istimewa di tengah masyarakat. Sastra lisan daerah dapat menjadi wahana pembelajaran untuk memahami masyarakat dan budayanya. Sastra lisan 
tidak bisa dilepaskan dari konteks kebudayaan.

Melalui deder masyarakat Dayak dapat mengomunikasikan identitas diri, kelas sosial dan budaya yang dimiliki. Identitas kultural merupakan konstruksi sosial dan dapat diekspresikan melalui berbagai bentuk representasi yang dapat dikenali oleh orang lain. Sehingga identitas dapat dimaknai melalui tanda-tanda seperti selera, kepercayaaan, sikap, gaya hidup, bahkan keterlibatan politis. Menurut Giddens dalam Barker, identitas adalah diri sebagaimana yang dipahami secara refleksif oleh orang dalam konteks biografinya. Weeks turut menyatakan dalam Barker, identitas adalah kesamaan Anda dengan sejumlah orang dan apa yang membedakan Anda dari orang lain.

Terkait konteks adat, deder digunakan sebagai perangkat pendukung upacara. Deder dapat dijadikan sebagai tanda yang memperluas makna dasar dalam konteks budaya. Deder lebih dari sekadar puisi yang dinyanyikan untuk menghibur, tapi juga merupakan sistem tanda yang saling terkait dengan sistemsistem tanda lain dalam masyarakat, dan melaluinya kita dapat mengirim pesan. Pesan ini dapat berupa sikap, status sosial kepercayaan politik dan seterusnya. Peneliti membatasi objek penelitian ini pada deder yang hidup di kota, Palangka Raya. Deder ini dipilih menjadi objek penelitian karena memiliki kekhasan yang berbeda dari deder lainnya. Masing-masing deder yang menjadi objek tersebut merupakan deder yang dipilih karena mempunyai keunikan tersendiri.

Tujuan penelitian ini adalah untuk mendeskripsikan struktur sastra lisan deder yang berhubungan dengan bait dan baris.

\section{TINJAUAN PUSTAKA}

Penelitian ini menggunakan teori strukturalisme dinamik. Strukturalisme dinamik mula-mula dikemukakan oleh Mukarovsky dan Felik Vodkka (Fokkema, 1977: 31). Lahirnya strukturalisme dinamik didasarkan atas kelemahankelemahan strukturalisme dan formalisme. Strukturalisme dinamik dimaksudkan sebagai penyempurnaan strukturalisme yang semata-mata memberikan perhatian terhadap struktur instrinsik, dan melupakan aspek-aspek estrinsiknya.

Strukturalisme dinamik beranggapan bahwa karya sastra adalah proses komunikasi, fakta semiotik, terdiri atas struktur dan nilai-nilai. Karya sastra adalah petanda yang memperoleh makna dalam kesadaran pembaca. Oleh karena itulah, karya sastra harus dikembalikan pada kompetensi penulis/penutur, masyarakat yang menghasilkannya, dan pembaca sebagai penerima. Secara definif strukturalisme memberikan perhatian terhadap analisis unsur-unsur karya sastra. Setiap karya sastra memiliki ciri yang khas, otonomi, tidak bisa digeneralisasikan. Meskipun demikian perlu dikemukakan unsur-unsur pokok yang terkandung dalam ketiga jenis karya sastra, yaitu prosa, puisi, dan drama. Atas dasar hakikat otonom karya sastra seperti di atas, maka tidak ada aturan yang baku terhadap suatu kegiatan analisis. Artinya, unsur-unsur yag dibicarakan tergantung dari dominasi unsur-unsur karya di satu pihak dan tujuan analisis di pihak lain. Dalam analisis selalu terjadi tarik-menarik antara struktur global, yaitu totalitas karya itu sendiri dengan unsur-unsur yang diadopsi ke dalam wilayah penelitian.

Menurut Jean Piaget, justru di sini 
tampak dinamika karya sastra sebagai totalitas. Proses adopsi mengandaikan terjadinya transformasi dan regulasi sehingga terjadi keseimbangan antara struktur global dengan unsur-unsur yang dianalisis. Karya sastra tidak mungkin dan tidak perlu dianalisis secara menyeluruh sebab struktur global tidak terbatas. Karya sastra tidak mungkin lepas dari kerangka sosiokulutral yang menghasilkannya. Oleh karena itu, karya sastra tidak semata-mata dianalisis sebagai teks, tetapi juga dimungkinkan dalam kaitannya dengan pementasan langsung, sebagai perfoming art. Dalam hubungan ini analisis strukur akan melibatkan paling sedikit tiga komponen utama, yaitu pencerita, karya sastra, dan pendengar.

Sebagai akumulasi konsep, teori tidak harus dipahami secara kaku. Teori tidak harus dan tidak mungkin diterapkan secara persis sama sebagaimana dikemukakan oleh para penemunya. Teori pun dapat ditafsirkan sesuai dengan kemampuan peneliti. Teori adalah alat, kapasitasnya berfungsi untuk mengarahkan sekaligus membantu untuk memahami objek secara maksimal. Teori memiliki fungsi statis sekaligus dinamis. Aspek statisnya adalah konsep-konsep dasar yang membangun sekaligus membedakan suatu teori dengan teori yang lain. Dalam strukturalisme, misalnya konsep-konsep dasarnya adalah unsur-unsur, antarhubungan, dan totalitasnya. Aspek dinamisnya adalah konsep-konsep dasar itu sendiri sesudah dikaitkan dengan objeknya.

Menurut struktralisme dinamik yang dikembangkan Ian Mukarovsky dan Felix Vodicka, memahami karya sastra berdasarkan kesadaran bahwa karya sastra sebagai struktur pada hakikatnya memiliki ciri khas yaitu sebagi tanda (sign). Tanda baru mendapat makna sepenuhnya bila sudah melalui tangan pembaca. Dengan demikian ada pengaruh timbal balik antara tanda dan pembacanya. Pembaca terikat pada konvensi tanda dalam memberi makna. Unsur-unsur yang terdapat pada tiga jenis sastra (prosa, puisi, dan drama) membutuhkan pemusatan analisis yang berdeda pula. Unsur-unsur prosa, misalnya mengarah pada tema, peristiwa atau kejadian, latar atau setting, penokohan, alur, sudut pandang, dan gaya bahasa. Unsur-unsur puisi, diantaranya tema, stilistika, imajinasi, ritme atau irama, rima atau persajakan, diksi atau pilihan kata, simbol, nada, dan enjambemen. Unsurunsur (teks) drama diantaranya tema, dialog, peristiwa, latar, penokohan, alur, dan gaya bahasa. Atas dasar hakikat otonomi sastra, maka tidak ada aturan yang baku terhadap suatu kegiatan analisis. Artinya, unsur-unsur yang dibicarakan tergantung dari dominasi unsur-unsur karya sastra di satu pihak dan tujuan analisis di lain pihak. Dalam analisis dapat terjadi tarik-menarik antara struktur global, yaitu totalitas karya itu sendiri dengan unsur-unsur yang diadopsi ke dalam wilayah penelitian. Kondisi tersbut menunjukkan dinamika karya sastra sebagai totalitas sebab proses adopsi mengandaikan terjadiya ciri-ciri transformasi dan regulasi diri sehingga terjadi keseimbangan antara struktur global dengan unsur-unsur yang dianalisis. Karya sastra tidak mungkin dan tidak perlu dianalisis secara menyeluruh sebab struktur global bersifat tidak terbatas. Akan tetapi, analisis tidak dapat dilepaskan dari kerangka sosio kultur yang 
menghasilkannya.

Menurut Noor (2004:78), struktur adalah keseluruhan relasi antara berbagai unsur sebuah teks. Strukturalisme adalah aliran ilmu dan kritik yang memusatkan perhatian pada relasi-relasi antarunsur. Menurut Mukarovsky (dalam Teeuw 1988:190), strukturalisme mengkaji karya sastra sebagai sebuah karya seni yang terwujud sebagai tanda dalam unsur instrinsiknya, dalam hubungannya dengan kenyataan dan dalam hubungannya dengan masyarakat, pencipta, dan pennggapnya. Teori struktural dinamik ini sangat erat kaitannya dengan pembaca. Pembaca diposisikan sebagi tolak ukur dalam menganalisis suatu karya sastra.

\section{METODE PENELITIAN}

Metode penelitian kualitatif merupakan cara untuk menafsirkan dan menyajikan data dalam bentuk deskriptif (Ratna, 2013: 46). Data-data yang telah ada kemudian ditafsirkan dan dianalisis untuk mendapatkan struktur deder. Penelitian ini menggunakan metode deskriptif analitik. Metode deskripsi analisis bisa didapatkan dari penggabungan dua metode yang saling mendukung (Ratna, 2013: 53). Kedua metode tersebut bertujuan untuk menguraikan informasi mendetail mengenai aspek-aspek struktur karya sastra dan menghubungkannya menjadi satu kesatuan. Sumber data yang digunakan ialah catatan deder yang dikumpulkan dari tujuh orang informan. Untuk memudahkan peneliti mendeskripsikan bentuk puisi deder. Data yang digunakan berasal dari bait-bait puisi deder. Data lain yang dibutuhkan yaitu informasi terkait kondisi geografis, kondisi budaya masyarakat, tepatnya di Kecamatan Rakumpit, Palangka Raya. Instrumen yang digunakan yaitu peneliti, wawancara narasumber selaku orang yang menguasai deder. Panduan teknik pengumpulan data yang. digunakan dalam penelitian ini adalah teknik dokumentasi yang dilakukan secara langsung melalui kamera, perekaman dilakukan dengan menggunakan alat perekam, pengamatan, selanjutnya pencatatan dilakukan ketika wawancara, dan wawancara dilakukan dengan menanyakan masalah terkait. Teknik analisis data yang digunakan model analisis isi. Model analisis isi menekankan pemaknaan isi komunikasi dan isi interaksi simbolik yang terjadi pada peristiwa komunikasi (Ratna, 2013: 49). Teknik ini dilakukan dengan mengumpulkan data mentah, mengolah data, membaca data berupa puisi deder kemudian mendiskripsikan struktur dan identitas kulutal yang terkandung di dalamnya.

\section{HASIL DAN PEMBAHASAN}

Sebagai sebuah sastra lisan berbentuk puisi, deder memiliki struktur dasar yang berupa bait dan baris. Struktur bait dan baris dalam deder dapat dijelaskan sebagai berikut.

\section{Bait}

Pada dasarnya deder dinyanyikan secara bersahut-sahutan antara dua orang tentang suatu hal. Setelah seseorang menyanyaikan satu bait deder, orang lain yang menjadi mitra deder menyahutnya dengan satu bait deder pula. Demikian terus menerus bait demi bait deder dinyanyikan secara bergantian.

Jumlah bait pada deder menjadi tidak terbatas. Jumlah bait pada deder sangat tergantung dari tema yang sedang 
dibicarakan. Jumlah bait juga tergantung pada kepiawaian orang yang berdeder dalam menanggapi bait-bait deder yang dilontarkan mitra dedernya. Perhatikanlah bentuk deder berikut ini.

\section{Bahasa Dayak Ngaju \\ LAKI-LAKI: \\ Tabe ku Salamat je tunda kula \\ Mina mama bakas tabela \\ PEREMPUAN \\ Aku nyarita je baya-baya Aku mangesah akan ketun tawa}

\section{LAKI-LAKI}

Hetuh aku mengesah apin nah gawi

Ikei bagawi hatuwe bawi

PEREMPUAN

Ikei bagawi ba are biti

Kurik hai dia balihi

LAKI-LAKI

Tulak sunsung je bara lewu

Ikei bagawi je supaya dinu

PEREMPUAN

Tulak bagawi harus tege inuju

Mangat gulung je are dinu

\section{LAKI-LAKI}

Bara hajewu sampai halem

Ikei bagawi dia tawan adaw halemei

\section{PEREMPUAN}

Hawi haranan je kanih kate

Ikei bagawi buli halemei

LAKI-LAKI

Ikei hapakat buli halemei

Cukup jadi ikei dinun are

\section{Bahasa Indonesia}

Tabe ku selamat saudaraku

Tante om tua muda

Aku bercerita sedikit

Aku bercerita supaya kalian tahu

Disini saya bercerita pekerjaan

Kami bekerja Laki-laki Perempuan

Kami bekerja banyak orang

Besar kecil tidak ketinggalan

Berangkat pagi dari kampung

Supaya bekerja bisa dapat banyak

Berangkat kerja harus ada tujuan

Supaya cepat dapat

Dari pagi sampai malam Kami bekerja lupa waktu

Ternyata sudah malam

Kami pun pulang malam

Kami sepakat pulang malam

Cukup banyak yag kami dapat

Bekerja kayu harus ada

PEREMPUAN $\begin{aligned} & \text { niat } \\ & \text { Bagawi kayu harus tege Supaya kita dapat berkat } \\ & \text { niat }\end{aligned}$
$\begin{aligned} & \text { Supaya tau je are ih } \begin{array}{l}\text { Sampai disini kata cerita } \\ \text { berkat }\end{array} \\ & \text { Untuk kita saudara }\end{aligned}$

LAKI-LAKI

Tikas tuh helu tadak Minta maaf kalau kata Sarita salah

Akan nah itah je tuda Karena lagu barujuga

Kula

PEREMPUAN

Minta maaf amun kutak ku sala

Hawi kanderang je haru kia.

Deder di atas dinyanyikan oleh Lakilaki dan Perempuan. Setiap bait, yang terdiri atas dua baris, selesai dinyanyikan, bait berikutnya dinyanyikan oleh mitra deder. Bait yang satu dengan bait yang lain saling berhubungan baik secara makna maupun secara persajakan. Perhatikan dua bait pertama dari deder di atas.

LAKI-LAKI

Tabe ku Salamat je tunda Tabe ku selamat kula saudaraku

Mina mama bakas tabela Tante om tua muda

PEREMPUAN

Aku nyarita je baya-baya Aku mangesah akan ketun tawa

Bait deder yang dinyanyikan seorang Laki-laki sebagai pembuka, dibalas oleh Perempuan dengan menyanyikan bait berikutnya. Dua bait itu masih sebagai bait pembuka. Bait-bait berikutnya sudah merupakan bait-bait yang menceritakan isi deder. Keunikan sistem pembaitan di sini adalah bahwa setiap bait yang dinyanyikan oleh Laki-laki maupun Perempuan alur ceritanya mengikuti cerita Laki-laki dan alur cerita Perempuan, meskipun persajakannnya saling menyesuaikan.

Misnawati*, Petrus Poerwadi**, dan Fitria Meta Rosia***

Universitas Palangkaraya 
Perhatikan alur cerita Laki-laki berikut berdasarkan bait-baitnya.

\section{Bahasa Dayak Ngaju}

LAKI-LAKI

Tabe ku Salamat je tunda kula

Mina mama bakas tabela

LAKI-LAKI

Hetuh aku mengesah apin nah gawi

Ikei bagawi hatuwe bawi

LAKI-LAKI

Tulak sunsung je bara lewu

Ikei bagawi je supaya dinu

\section{LAKI-LAKI}

Bara hajewu sampai Daripagi sampai malam halemei

Ike bagawi dia tawan Kami bekerja lupa waktu adaw halemei

LAKI-LAKI

Ikei hapakat buli halemei

Cukup jadi ikei dinun are

\section{LAKI-LAKI}

Tikas tuh helu tadak Sampaidisini kata cerita

Sarita

Akan nah itah je tuda Untuk kita saudara

Kula

Perhatikan pula bait-bait yang diceritakan oleh pendeder Perempuan berikut ini.

Bahasa Dayak Ngaju

\section{PEREMPUAN}

Aku nyarita je baya-baya

Aku mangesah akan ketun tawa
Bahasa Indonesia
Disini saya bercerita tentang kerjaan Perempuan

Berangkat pagi dari kampung

$$
\text { Hawi kanderang je haru kia. }
$$

Kami bekerja Laki-laki Minta maaf amun kutak ku

orang

Besar kecil tidak ketinggalan

PEREMPUAN

Tulak bagawi harus tege inuju

Berangkat kerja harus ada tujuan

Supaya cepat dapat

Ternyata sudah malam Kami pun pulang malam

\section{PEREMPUAN}

Bagawi kayu harus tege niat

Supaya tau je are ih berkat

Bekerja kayu harus ada niat

Supaya kita dapat berkat

Bait-bait yang dinyanyikan oleh Laki-laki membentuk satu alur cerita. Demikian pula bait-bait yang dinyanyikan oleh Perempuan membentuk satu alur cerita. Namun demikian persajakan pada bait-bait itu tetap mengikuti kaidah persajakan.

Dari segi fungsi baitnya, bait-bait Kami sepakat pulang malam pada deder di atas dapat diidentifikasi Cukup banyak yag kami dapat sebagai bait pembuka, bait isi dan bait penutup. Pada deder di atas bait pembuka dinyanyikan oleh Laki-laki dan Perempuan. Bait penutupnya juga dinyanyikan oleh Laki-laki dan Perempuan. Demikian pula, bait isi dinyanyikan baik oleh Perempuan maupun Laki-laki. Dengan demikian, baik bait pembuka, isi, maupun penutup dinyanyikan baik oleh Perempuan maupun Laki-laki. Perhatikanlah pembagian bait pada deder berikut ini.

Aku bercerita sedikit

Aku bercerita supaya kalian tahu

Bahasa Dayak Ngaju

Fungsi Bait

PEREMPUAN

Ikei bagawi ba are biti Kami bekerja banyak 
LAKI-LAKI

Tabe ku Salamat je tunda kula Bait Pembuka

Mina mama bakas tabela

PEREMPUAN

Aku nyarita je baya-baya

Bait

Aku mangesah akan ketun tawa

Pembuka

LAKI-LAKI

Hetuh aku mengesah apin nah Bait Isi gawi

Ikei bagawi hatuwe bawi

PEREMPUAN

Ikei bagawi ba are biti

Kurik hai dia balihi

Bait Isi

LAKI-LAKI

Tulak sunsung je bara lewu

Ikei bagawi je supaya dinu

Bait Isi

PEREMPUAN

Tulak bagawi harus tege inuju Bait Isi

Mangat gulung je are dinu

LAKI-LAKI

Bara hajewu sampai halemei

Ikei bagawi dia tawan adaw

halemei

PEREMPUAN

Hawi haranan je kanih kate

Ikei bagawi buli halemei

LAKI-LAKI

Ikei hapakat buli halemei

Cukup jadi ikei dinun are

PEREMPUAN

Bagawi kayu harus tege niat

Supaya tau je are ih berkat

LAKI-LAKI

Tikas tuh helu tadak Sarita

Akan nah itah je tuda Kula

PEREMPUAN

Minta maaf amun kutak ku sala

Hawi kanderang je haru kia.

Berdasarkan uraian di atas dapat disimpulkan bahwa:

Bait Isi

a. Jumlah bait dalam setiap deder tidak tentu, bergantung topik dan kreativitas pendeder.

b. Setiap bait deder terdiri atas dua baris.

c. Struktur bait deder terdiri atas : pembukaan, isi, dan penutup.

d. Bait pembukaan, isi dan penutup dinyanyikan oleh baik pendeder Perempuan maupun Laki-laki.

\section{Baris}

Dalam setiap bait deder terdapat dua baris. Setiap baris terdiriatastiga sampai enam kata. Dalam setiap baris terdiri atas delapan sampaitigabelassukukata.

Perhatikancontoh deder berikut ini.

\section{Bahasa Dayak Ngaju}

Bait Isi

Bait Isi

Bait Isi

Bait Penutup

Bait

Penutup
Tabe Salamat Salabih helu

Dengan nah ketun sambil gantau

Balaku maaf je bara aku

Dengan nah ketun kawan pahariku

Belum nah damai jite je gau

Mangat nah itah belum dia kana kambehu

Itah bapander injaga selalu

Mangat nah uluh dia ngbehu

Haranan belum intu dunia

Are uluh manggau kasala

Maka dari jite keleh itah mahaga

Kutak pander itah dengan tunda kula

Kadamai tege intu dunia

Awei itah tau mahaga

Damai dunia damai hati kia

\section{Jumlah Kata/ Suku Kata}

4 kata $\quad 10$

suku kata

5 kata $\quad 10$

suku kata

5 kata 10

suku kata

5 kata 11

suku kata

6 kata $\quad 10$

suku kata

7 kata 14

suku kata

$\begin{array}{ll}\begin{array}{l}\text { 4 kata } \\ \text { suku kata }\end{array} & 11 \\ 5 \text { kata } & 10 \\ \text { suku kata } & \\ 4 \text { kata } & 10 \\ \text { suku kata } & \\ 4 \text { kata } & 10 \\ \text { suku kata } & \\ 6 \text { kata } & 13 \\ \text { suku kata } & \\ 6 \text { kata } & 12 \\ \text { suku kata } & \\ 4 \text { kata } & 10 \\ \text { suku kata } & \\ 4 \text { kata } & 9 \text { suku } \\ \text { kata } & \\ 5 \text { kata } & 11\end{array}$

Misnawati*, Petrus Poerwadi**, dan Fitria Meta Rosia***

Universitas Palangkaraya 


$\begin{array}{llll} & \text { suku kata } & \\ \text { Awei nah uluh tau marega } & 4 \text { kata } & 10 \\ & \text { suku kata } & \\ \text { Awei itah belum tu dunia } & 5 \text { kata } & 10 \\ & \text { suku kata } & \\ \text { Gau badamai dari pada kalahi } & 6 \mathrm{kata} & 14 \\ \text { kia } & \text { suku kata } & \\ \text { Cukup genep jadi inyarita } & 4 \text { kata } & 10 \\ & \text { suku kata } & \\ \text { Akan ketun je tunda kula } & 5 \text { kata } & 9 \text { suku } \\ & \begin{array}{l}\text { kata } \\ \text { Tikas tuh helu auh dederku }\end{array} & 5 \text { kata } & 10 \\ & \text { suku kata } & \\ \text { Akan itah je pahariku } & 4 \text { kata } & 9 \text { suku } \\ & \text { kata } & \\ \text { Jaga tarus auh kutak panderMu } & 5 \text { kata } & 11 \\ & \text { suku kata } & \\ \text { Mangat nah ikau dia kana ganggu } & 6 \text { kata } & 11 \\ & \text { suku kata } & \end{array}$

Berkaitan dengan baris-baris dalam deder, perlu diperhatikan pula contoh deder yang dibuat sekitar tahun 1985. Contoh ini ditampilkan untuk sekedar melihat perbandingan deder yang dibuat sekitar 30 dengan deder yang dibuat oleh generasi muda. Perhatikan deder berikut ini.

\section{Deder Bahasa Dayak Ngaju}

LAKI-LAKI

Bara kejau sama pancarjambun, 5 kata 10 suku kata

Sekali nukep tapi tahijau daun. $5 \quad$ kata 12 suku kata

PEREMPUAN

Kusadang unting nduang sadang 5 kata unting,

Kukurik bereng kuhayak 4 kata tumamating. 12 suku kata

\section{LAKI-LAKI}

Ela aum je macam kalute,

Je arep mahin dia sarene.

$5 \quad$ kata

10 suku kata

$5 \quad$ kata

10 suku kata

PEREMPUAN

Leha-lehan katamam au, $\quad 3$ kata 9 suku kata

Kusuma ajar awi bapa indu

LAKI-LAKI

Eweh dia talu kalute)
Sama mahining atey kapehe.

10 suku kata

$\begin{array}{llr}\text { PEREMPUAN } & 5 & \text { kata } \\ \text { Jaka kukakam anak burung } & 11 \text { suku kata } \\ \text { bubut, } & 4 r \text { kata } \\ \text { Ikaw inyambar palus mangkut, } & 9 \text { suku kata }\end{array}$

LAKI-LAKI 4 kata

Tumbang Kapuas hulek 11 suku kata hatambeleng 4 kata Lewu Basarang kusandehen 11 suku kata bereng.

PEREMPUAN 5 kata Tarik tandu je tarik tandu, 9 suku kata

$6 \quad$ kata

Ie jagau bidu je pamanuk 11 suku kata lewu.

\section{LAKI-LAKI}

$5 \quad$ kata

Eweh tempu nduang eweh 11 suku kata tempu, 5 kata Kumanuk rangkang tambalik 10 suku kata bulu.

\section{LAKI-LAKI}

Eweh atije uluh tempu,

$5 \quad$ kata 9 suku kata $6 \quad$ kata Pea beken bara bapa ndue indu. 12 suku kata

LAKI-LAKI 5 kata Gasak tarus pahari gasak tarus, 11 suku kata 5 kata Tempulu angin itah jadi 11 suku kata bagus.

LAKI-LAKI 4 kata Mbuhen auh nduang hunu- 10 suku kata hunum, 4 kata Kusama rumet penda danum 9 suku kata

PEREMPUAN 4 kata

Ela mite manuk rangkang melai, 10 suku kata $4 \quad$ kata Je dia tau awi barangai. $\quad 10$ suku kata

LAKI-LAKI 5 kata Ela mahamen, mina, ela 12 suku kata mahamen, 5 kata Kumanarik deder adad itah 13 suku kata kalunen.

$\begin{array}{llr}\text { PEREMPUAN } & 5 & \text { kata } \\ \text { Kilen ampi ku dia kudenga, } & 10 \text { suku kata } \\ \text { Nasib bereng kabuat nyarena } & 410 \text { suku kata }\end{array}$

Misnawati*, Petrus Poerwadi**, dan Fitria Meta Rosia*** 


\begin{tabular}{|c|c|}
\hline LAKI-LAKI & $3 \quad$ kata \\
\hline Nandehan kaputus Rampang, & 8 suku kata \\
\hline & $5 \quad$ kata \\
\hline Dia nyelu jetuh nyelu rahian. & 11 suku kata \\
\hline PEREMPUAN & $5 \quad$ kata \\
\hline Pea dia atey tuh kalutuh, & 10 suku kata \\
\hline & $5 \quad$ kata \\
\hline $\begin{array}{l}\text { Je belum susah manyengkelang } \\
\text { uluh. }\end{array}$ & 11 suku kata \\
\hline LAKI-LAKI & $3 \quad$ kata \\
\hline Leha-lehan katamam au & 9 suku kata \\
\hline & $5 \quad$ kata \\
\hline Sama ajar awi bapa indu. & 10 suku kata \\
\hline PEREMPUAN & \\
\hline Taluh bewei taluh bewei, & $\begin{array}{l}4 \text { kata } \\
9 \text { suku kata }\end{array}$ \\
\hline $\begin{array}{l}\text { Galumbang belum pandehan } \\
\text { matey }\end{array}$ & $\begin{array}{l}4 \quad \text { kata } \\
10 \text { suku kata }\end{array}$ \\
\hline LAKI-LAKI & \\
\hline Memang aku dia je ajar indu, & $\begin{array}{l}6 \quad \text { kata } \\
11 \text { suku kata }\end{array}$ \\
\hline Kalantih ayungku je bara helu. & $\begin{array}{l}5 \quad \text { kata } \\
11 \text { suku kata }\end{array}$ \\
\hline
\end{tabular}

Dalam deder di atas, jumlah kata dalam satu baris antara tiga sampai enam kata. Jumlah suku kata setiap barisnya adalah delapan sampai tiga belas suku kata. Jumlah kata dan suku kata sebenamya tidak dapat ditentukan secara pasti. Jumlah suku kata ditentukan juga oleh irama musik deder yang mengiringinya.

Baris pertama dalam deder, kadang-kadang tidak bertautan maknanya dengan baris kedua. Baris pertama dalam deder mirip sampiran dalam pantun, hanya berfungsi sebagai pengumpan untuk menyamakan persajakannya dengan baris kedua. Perhatikan contoh berikutini.

Bahasa Dayak Ngaju

(1) Pea kea ikey enta-entai,

Ku kueh tandu pahari bara mandomai

(2) Tandun manuk je tandun haruei

\section{Bahasa Indonesia}

Sampai kapan

Mana kokok saudara Mandomai.
Batang danum je nyangka Sungai besar kukira ku sungai

sungai.'

Perhatikan baris pertama dari bait (1) deder di atas berbunyi Pea kea ikeyenta-entai 'Sampai kapan kamumenunggu'. Makna baris pertama tersebut tidak bertautan dengan makna baris kedua yang berbunyi Kukuehtandupahari bara mandomai 'mana kokoksaudaradariMandomai'. Demikian pula pada bait nomor dua dari deder di atas, baris pertamanya berbunyi Tandun manuk je tandun haruei'Kokok ayamkokok burungharuei' maknanya tidak bertautan dengan baris kedua yang berbunyiBatang

danumjenyangkakusungai'Sungaibesarkuk ira anaksungai'. Oleh karena itu dapat disimpulkan bahwa baris pertama pada bait deder dapat berupa pengumpan, semacam sampiran dan baris kedua merupakan isi pada bait itu. Memang tidak semua bait deder berpola seperti itu. Ada pula yang baris pertama dan baris keduanya memiliki pertautan arti. Perhatikan contoh di bawah ini.

Bahasa Dayak Ngaju

(1)Aku nyarita je bayabaya

Aku mangesah akan ketun tawa

(2) Ikei bagawi ba are biti

Kurik hai dia balihi

\section{Bahasa Indonesia}

Aku bercerita sedikit

$\mathrm{Aku}$ bercerita supaya kalian tahu

Kami bekerja banyak orang Besar kecil tidak ketinggalan

kamu

dari Perhatikan baris pertama dari bait (1) deder di atas berbunyi Aku nyarita je baya-baya 'Aku bercerita sedikit'. Makna baris pertama 'Kokok ayam kokok burung
haruei 
kedua yang berbunyi Aku mangesah akan ketun tawa'Aku bercerita supaya kalian tahu'. Demikian pula pada bait nomor dua dari deder di atas, baris pertamanya berbunyi Ikei bagawi ba are biti'Kami bekerja banyak orang' maknanya bertautan dengan baris kedua yang berbunyiKurik hai dia balihi'Besar kecil tidak ketinggalan'. Oleh karena itu dapat disimpulkan bahwa baris pertama pada bait deder maknanya dapat bertautan dengan baris keduanya.

Berdasarkan uraian tentang baris di atas dapat disimpulkan halhal sebagai berikut:

a. Jumlah kata dalam satu baris adalah tiga sampai tujuhkata.

b. Jumlah suku kata dalam setiap barisnya adalah delapan sampai tiga belas suku kata.

c. Baris pertama dapat berupa pengumpan dapat pulabertautan makna dengan baris kedua.

\section{KESIMPULAN}

Bait dalam deder berbentuk: (a) Jumlah bait dalam setiap deder tidak tentu, bergantung topik dan kreativitas pendeder. (b) Setiap bait deder terdiri atas dua baris. (c) Struktur bait deder terdiri atas: pembukaan, isi, dan penutup. (d) Bait pembukaan, isi dan penutup dinyanyikan oleh pendeder Perempuan maupun Lakilaki.

Baris dalam deder berbentuk berbentuk: (a) jumlah kata dalam satu baris adalah tiga sampai tujuh kata. (b) jumlah suku kata dalam setiap barisnya adalah delapan sampai tiga belas suku kata. (c) baris pertama dapat berupa pengumpan, dapat pula bertautan makna dengan baris.
Saran bagi peneliti penelitian selanjutnya yaitu masih dapat diteliti objek yang lain seperti gaya bahasa dalam dalam deder, imaji, dan kohesi dan koherensi dalam deder. Selain itu, penulis juga menyarankan kalau deder perlu untuk selalu dipertahankan dan. Penulis menyadari penelitian ini tidak dapat terlaksana dan terselesaikan tanpa bantuan dari berbagai pihak. Oleh sebab itu, penulis mengucapkan terimakasih kepada semua pihak yang telah mendukung penyusunan laporan ini terutama untuk Universitas Palangka Raya yang telah membiayai penelitian ini, untuk para informan, para mahasiswa yang telah membantu memberikan dan mengumpulkan data untuk penulis. Selain itu, penulis juga berterima kasih kepada jurnal Pedagogik UMP Palangka Raya karena telah bersedia membantu menerbitkan artikel ini.

\section{DAFTAR PUSTAKA}

Endraswara, Suwardi. 2013. Metodelogi Penelitian Sastra. Yogyakarta: CAPS.

Militan. 2016. Kabupaten Katingan dalam Angka. Kasongan: Badan Pusat Statistik Kabupaten Katingan.

Misnawati. 2015. "Hiyang Wadian Dayak Maanyan di Kabupaten Barito Timur (Kajian Ekopuitika)." Surabaya: Universitas Negeri Surabaya. (Disertasi, tidak diterbitkan).

Muntazir. 2017. Struktur Fisik dan Struktur Batin pada Puisi Tuhan, Aku Cinta Padamu Karya WS Rendra. Jurnal Pesona, 3 (2):208223.

Nasution, S. 1996. Metode Penelitian Naturalistik Kualitatif. Bandung: 
Tarsito.

Ong, Aihwa and Donald Nonin. 1997 .The Cultural Politics of Modern Chinese Transnationalism. New York \& London: Routledge.

Pateda, Mansoer. 2010. Semantik. Leksikal. Bandung : Rineka Cipta.

Prawirasumantri, Abud, dkk. 1997. Semantik Bahasa Indonesia. Jakarta:Depdikbud.

Putra, Chandra Anugrah. 2017. Pemanfaatan Teknologi Gadget Sebagai Media Pembelajaran. Bitnet: Jurnal Pendidikan Teknologi Informasi, 2(2):1-10.

Ratmanto, Teguh. 2004. Pesan: Tinjauan Bahasa, Semiotika, dan Hermeneutika. Jurnal MediaTor, 5(1): 29-37.

Ratna, Nyoman Kutha. 2013. Teori, Metode,dan Teknik Penelitian Sastra. Yogyakarta: Pustaka Pelajar.

Riadin, Agung. 2019. Implementasi Pembelajaran PKn untuk Membentuk Pribadi yang Berkarakter di SD Muhammadiyah Sampit. Pedagogik: Jurnal Pendidikan, 14(1):18-28.

Ricoeur, Paul. 2006. Hermeneutik dan Ilmu Sosial, terjemahan Muhammad Syukri. Yogyakarta: Kreasi Wacana.

Setiawan, Eko. 2015. Nilai-Nilai Religius dalam Syair Shalawat Burdah. Jurnal Lingua,10(1): 1--8.

Teeuw, A. 2012. Sastra dan Ilmu sastra. Jakarta : Dunia Pustaka Jaya.

Zaim, M. 2014. Metode Penelitian Bahasa: Pendekatan. . Jakarta : Dunia Pustaka Jaya. 